\title{
Inhibitory Activity of the Hypoxia-inducible Factor-1 Pathway by Tartrolone C
}

\author{
Yohko Yamazaki, Tetsuya Someno, Kazuhisa Minamiguchi, Manabu Kawada, \\ Isao Momose, Naoko Kinoshita, Hiroyasu Doi, Daishiro Ikeda
}

Received: July 19, 2006 / Accepted: October 26, 2006

(C) Japan Antibiotics Research Association

\begin{abstract}
Hypoxia-inducible factor-1 (HIF-1) is a central mediator of cellular responses to low oxygen and has recently become an important therapeutic target for solid tumor therapy. To identify small molecule inhibitors of the HIF-1 transcriptional activation, we have established a high through-put assay system using a stable transformant of mammalian cells that express a luciferase reporter gene construct containing a HIF-1 binding site. Using this system, we screened 5,000 cultured broths of microorganisms, and we found that fermentation broth produced by Streptomyces strain 1759-27 showed significant inhibition of the reporter activity induced by hypoxic conditions. The active substance NBR1759-27 was purified and determined to be tartrolone $\mathrm{C}$ by several methods including X-ray crystallography. In the reporter gene assay, tartrolone $\mathrm{C}$ inhibited the HIF-1 transcriptional activity under hypoxic conditions with an $\mathrm{IC}_{50}$ value of $0.17 \mu \mathrm{g} / \mathrm{ml}$.
\end{abstract}

Keywords hypoxia, hypoxia-inducible factor-1, tartrolone C, X-ray crystallography, reporter gene assay

\section{Introduction}

Angiogenesis is a key step in the tumor progression, invasion and metastasis, and vascular endothelial growth factor (VEGF) plays an important role during this step [1]. The expression of VEGF is regulated by hypoxia. Hypoxia is a common feature of many solid tumors and contributes to their progression. Hypoxic tumor cells are resistant to conventional chemotherapy and radiotherapy and hypoxia promotes a more malignant phenotype [2]. The transcription of VEGF is enhanced under hypoxic conditions and controlled primarily by hypoxia inducible factor-1 (HIF-1). HIF-1 is a central mediator of cellular responses to low oxygen and has recently become an important therapeutic target for solid tumor therapy. HIF-1 is a heterodimeric transcription factor composed of HIF- $1 \alpha$ and HIF- $1 \beta$. HIF- $1 \beta$, also known as the aryl hydrocarbon receptor nuclear translocator, is constitutively present in normoxic cells. In contrast, the HIF-1 $\alpha$ protein levels are primarily dependent on the intracellular oxygen concentration [3]. Under normoxic conditions, the HIF-1 $\alpha$ protein is hydroxylated by prolyl hydroxylases which require oxygen for their activity, and once hydroxylated, HIF- $1 \alpha$ rapidly binds to $\mathrm{pVHL}$, which is the recognition component of an E3 ubiquitin-protein ligase activity [4, 5], and then rapidly and continuously degraded by ubiquitination and proteasomal degradation $[6,7]$.

Recently several small-molecule inhibitors of HIF-1 pathway such as an Hsp90 inhibitor geldanamycin, a topoisomerase I inhibitor topotecan and an antimicrotubule agent vincristine [8 11] have been identified and chetomin, a disrupter of HIF-1 binding to p300, attenuated tumor growth through the disruption of HIF-1 pathway in vivo [12].

We previously established a high through-put assay system using a stable transformant of mammalian cells that expressed the luciferase gene under the control of the

Y. Yamazaki (Corresponding author), T. Someno, K. Minamiguchi, M. Kawada, I. Momose, D. Ikeda: Numazu BioMedical Research Institute, Microbial Chemistry Research Center, 18-24 Miyamoto, Numazu-shi, Shizuoka 410-0301, Japan, E-mail: yamako@bikaken.or.jp

N. Kinoshita, H. Doi: Microbial Chemistry Research Center, 3-14-23 Kamiosaki, Shinagawa-ku, Tokyo 141-0021, Japan 
hypoxia-response element [13]. To identify novel HIF-1 pathway inhibitors, we screened the broths of microorganisms using this system, and found that NBR1759-27 inhibited the HIF-1 transcriptional activity under hypoxic conditions. In this paper, we describe the isolation, crystal structure and biological activity of NBR1759-27.

\section{Materials and Methods}

\section{Fermentation}

The slant culture of strain was inoculated into a $500-\mathrm{ml}$ Erlenmeyer flask containing $110 \mathrm{ml}$ of the seed medium composed of galactose $1.0 \%$, dextrin $1.0 \%$, soypeptone $0.5 \%$, corn steep liquor $0.25 \%$, glycerol $0.5 \%,\left(\mathrm{NH}_{4}\right)_{2} \mathrm{SO}_{4}$ $0.1 \%, \mathrm{CaCO}_{3} 220 \mathrm{mg} /$ flask, $\mathrm{pH} 7.4$, and cultured for 8 days at $27^{\circ} \mathrm{C}$. One $\mathrm{ml}$ of the seed culture was then inoculated into $500-\mathrm{ml}$ Erlenmeyer flasks containing $200 \mathrm{ml}$ of the production medium composed of sucrose $2.0 \%$, corn steep liquor $1.0 \%, \mathrm{CaCO}_{3} 220 \mathrm{mg} /$ flask, $\mathrm{pH} 7.2$, and cultured for 12 days at $27^{\circ} \mathrm{C}$ on a rotary shaker.

\section{X-Ray Structure Analysis}

A colorless needle crystal of NBR1759-27 $(0.14 \times 0.03 \times 0.03 \mathrm{~mm})$ was mounted in a loop. All measurements were made on a Bruker SMART APEX II ULTRA diffractometer with monochromated intense Mo$\mathrm{K} \alpha$ radiation. The Mo radiation was produced by a rotating anode generator (TXS) combined with a multilayer confocal mirror (Helios). Crystal data: Empirical formula; $\mathrm{C}_{46} \mathrm{H}_{68} \mathrm{BNaO}_{18}$, Formula weight; 942.80, Crystal system; orthorhombic, Space group; P2(1)2(1)2(1), Lattice parameters; $\quad a=10.659(5) \AA, \quad b=17.404(8) \AA$, $c=27.229(13) \AA$, Volume; 5051(4) $\AA^{3}, Z$ value; $4, D_{\text {calc }}$; $1.240 \mathrm{Mg} / \mathrm{m}^{3}$, Absorption coefficient; $0.101 \mathrm{~mm}^{-1}$, The reflection data were collected at $90 \mathrm{~K}$ using $\omega$ scans. The structure was solved by a direct method (SHELXS-97).

\section{Cell Lines and Reagents.}

A stable transformant of $\mathrm{CHO}$ cells was established by the transfection of the HIF-1-dependent luciferase $(5 \times \mathrm{HRE} / \mathrm{pGL} 3 / \mathrm{VEGF} / \mathrm{E} 1 \mathrm{~b})$ and neomycin resistant genes as previously described [8]. Stably transfected cells were maintained in $\alpha$-MEM supplemented with $10 \%$ fetal bovine serum (ICN Biomedicals, Costa Mesa, CA, USA) and kanamycin $(50 \mu \mathrm{g} / \mathrm{ml})$. HCT- 8 human colorectal adenocarcinoma cells and MCF-7 human breast cancer cells were maintained in RPMI1640 with 10\% fetal bovine serum and kanamycin $(50 \mu \mathrm{g} / \mathrm{ml})$. Cells were cultured at $37^{\circ} \mathrm{C}$ in a humidified incubator containing $5 \% \mathrm{CO}_{2}$ (normoxia). Hypoxic treatment was performed by incubating cells at $37^{\circ} \mathrm{C}$ in an air-tight chamber (Forma Scientific Inc, Marietta, OH, USA) filled with a mixture of $90 \% \mathrm{~N}_{2}, 5 \% \mathrm{CO}_{2}$ and $5 \% \mathrm{H}_{2}$.

\section{Reporter Gene Assay}

Stably transfected cells were seeded at $1 \times 10^{4}$ cells/well in 96-well microplates one day before the following treatment. They were treated with drugs for 15 hours under hypoxic conditions, and then harvested for determination of the luciferase activity. The assay was carried out using a Luciferase Assay System from Promega.

\section{Western Blotting}

HCT- 8 and MCF-7 cells were seeded at $2 \times 10^{5}$ cells/well in 6 -well plates one day before the following treatment. They were treated with NBR1759-27 for 15 hours under hypoxic conditions. Treated cells were washed with ice-cold PBS containing $0.1 \mathrm{mM} \mathrm{Na}_{3} \mathrm{VO}_{4}$ and then lysed in a lysis buffer (20 mM HEPES, $150 \mathrm{mM} \mathrm{NaCl}, 1.0 \%$ Triton X-100, $10 \%$ glycerol, $1.0 \mathrm{mM}$ EDTA, $50 \mathrm{mM} \mathrm{NaF}, 50 \mathrm{mM} \beta$ glycerophosphate, $1.0 \mathrm{mM} \mathrm{Na}_{3} \mathrm{VO}_{4}$ and $25 \mu \mathrm{g} / \mathrm{ml}$ each of antipain, leupeptin, and pepstatin). The protein concentration of the lysates was determined using a Protein Assay Kit (Bio-Rad, Hercules, CA, USA). Equal protein extracts $(50 \mu \mathrm{g})$ were separated by SDS-PAGE and transferred onto an Immobilon polyvinylidene fluoride (PVDF) membrane filter (Milipore, Bedford, MA, USA). The membranes were blocked for 1 hour at room temperature with blocking buffer and then incubated with primary antibodies specific for HIF-1 $\alpha(1: 200$ dilution, BD Bioscience) or $\beta$-actin $(1: 5,000$ dilution, Sigma Aldrich Japan). The membranes were then washed and chemiluminescence detection was performed using peroxidase-conjugated secondary antibodies.

\section{Results and Discussion}

\section{Isolation of NBR1759-27}

The cultured broth (5 liters) was centrifuged at $3000 \mathrm{rpm}$ for 20 minutes. The broth was extracted with 4 liters of ethyl acetate and concentrated under reduced pressure to yield oily material. The material was dissolved in $\mathrm{CHCl}_{3}$ and applied on a silica gel column $(150 \mathrm{~g})$, and eluted with $\mathrm{CHCl}_{3}$. The active fractions $(67.9 \mathrm{mg})$ were applied on a LH-20 column and eluted with $1: 1(\mathrm{v} / \mathrm{v})$ of $\mathrm{CHCl}_{3}$ $\mathrm{MeOH}$. The fractions containing NBR1759-27 (57.8 mg) were further purified by HPLC (column; Capcell Pak $\mathrm{C}_{18}$, SHISEIDO, $20 \times 250 \mathrm{~mm}$; solvent, $45 \% \mathrm{CH}_{3} \mathrm{CN}$; detection, $\mathrm{UV}$ at $230 \mathrm{~nm}$; flow rate, $6.0 \mathrm{ml} /$ minute). Under these 


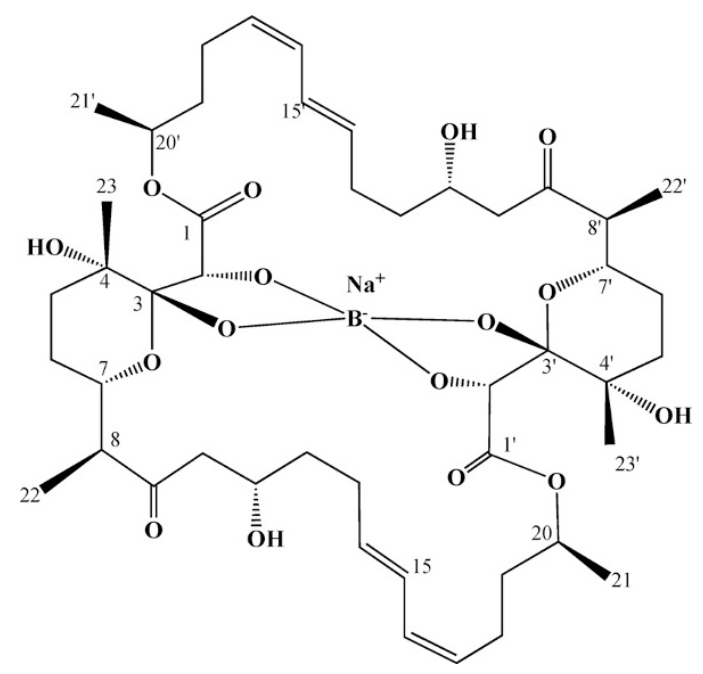

Fig. 1 Relative structure of NBR1759-27.

conditions, NBR1759-27 was eluted as a peak with retention time of 50 minutes. The pooled fractions were concentrated under reduced pressure to give pure NBR1759-27 (46.1 mg) as white powders. It was crystallized from $\mathrm{CHCl}_{3}-\mathrm{MeOH}$ to give colorless needles. mp. 207 210 ${ }^{\circ} \mathrm{C}(\mathrm{dec}) ; \mathrm{UV}(\mathrm{MeOH}) \lambda_{\max } \mathrm{nm}(\varepsilon) 232$ (30200); $[\alpha]_{\mathrm{D}}^{23}+26.9(c 0.13, \mathrm{MeOH}) ;$ HRESI-MS $(m / z)$ 933.4379 $(\mathrm{M}+2 \mathrm{Na})^{+}$(calcd for $\mathrm{C}_{46} \mathrm{H}_{68} \mathrm{BNa}_{2} \mathrm{O}_{16}$, 933.4396).

\section{Identification of the Active Substance as Tartrolone C}

The planar structure of NBR1759-27 was identified as tartrolone $\mathrm{C}[14]$ by comparing their spectral data including ${ }^{1} \mathrm{H}$ and ${ }^{13} \mathrm{C}$ NMR. The relative structure shown in Fig. 1 was confirmed by the X-ray crystallography of NBR175927 as described bellow.

\section{The Crystal Structure of NBR1759-27}

The stereochemistry of tartrolone B, a closely related compound of tartrolone $\mathrm{C}$, was determined by the $\mathrm{X}$-ray crystallography. On the other hand, the relative stereochemistry of tartrolone $\mathrm{C}$ was reported to be same as that for tartrolone B based on the positive sign of the optical rotation and NOESY experiments [14]. To confirm the stereochemistry of NBR1759-27, we carried out X-ray crystallography of NBR175-27 using a single crystal grown from $\mathrm{CHCl}_{3}-\mathrm{MeOH}$ solution. Fig. 2 shows the ORTEP drawing of NBR1759-27.

\section{Biological Activities}

To identify novel small molecules targeting the HIF-1 pathway, we transfected Chinese hamster ovary (CHO) cells with a luciferase reporter gene construct containing 5

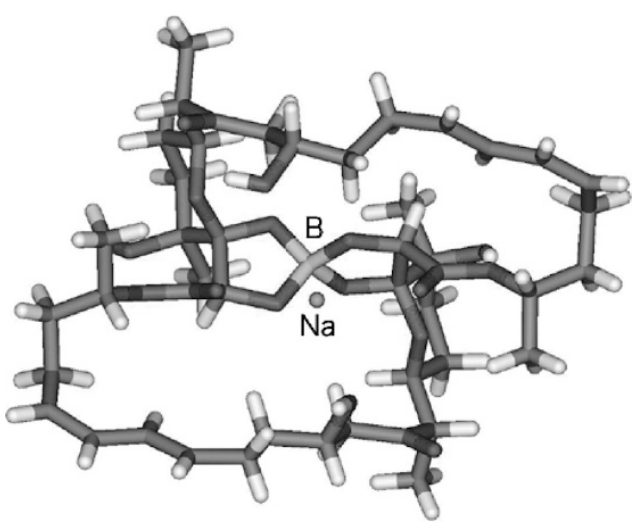

Fig. 2 Crystal structure of NBR1759-27.

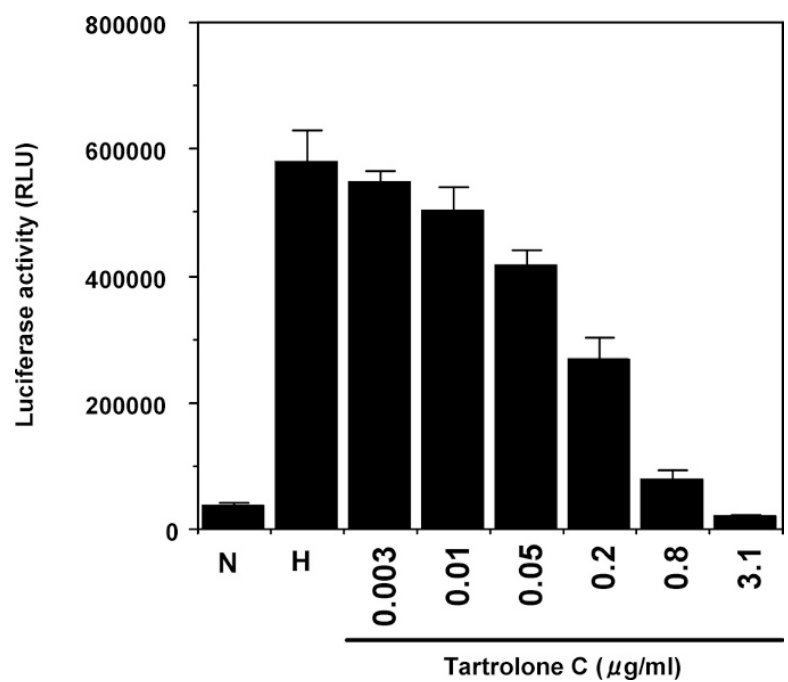

Fig. 3 Effect of tartrolone $\mathrm{C}$ on the expression of the VEGF promoter reporter gene.

$\mathrm{N}$ : normoxic condition, $\mathrm{H}$ : hypoxic condition.

copies of a HIF-1 binding site derived from the human VEGF promoter and established a stable clone. In this assay system, the HIF-1 transcriptional activity was significantly inhibited by tartrolone $\mathrm{C}$ in a dose-dependent manner under hypoxic conditions with an $\mathrm{IC}_{50}$ value of $0.17 \mu \mathrm{g} / \mathrm{ml}$ (Fig. 3). Tartrolone $\mathrm{C}$ did not show any cytotoxic effects at the concentrations used in this experiment.

We then examined the effect of tartrolone $\mathrm{C}$ on the HIF$1 \alpha$ protein expression by Western blot. As shown in Figs. $4 \mathrm{~A}$ and $4 \mathrm{~B}$, tartrolone $\mathrm{C}$ decreased the hypoxic induction of the HIF- $1 \alpha$ protein in HCT-8 human colorectal adenocarcinoma cells and MCF-7 human breast cancer cells. This decrease of HIF- $1 \alpha$ protein is one of factors that cause the inhibition of HIF-1 transcriptional activity. 
A

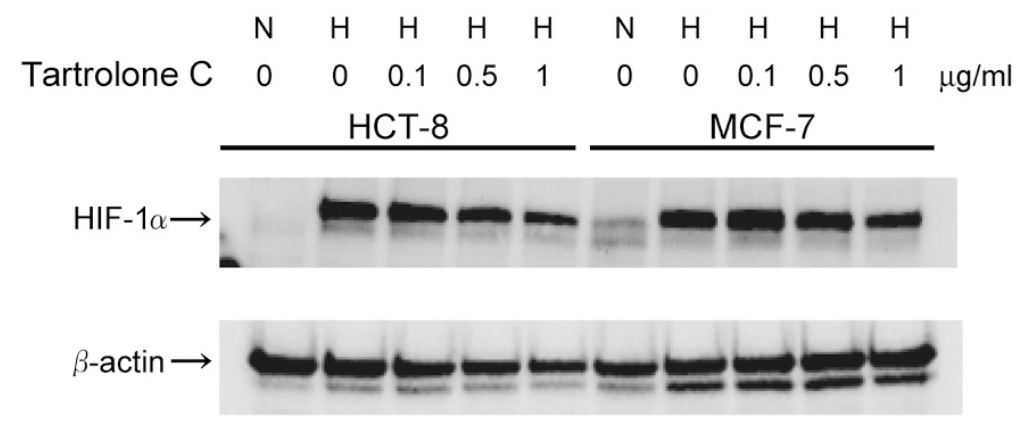

B
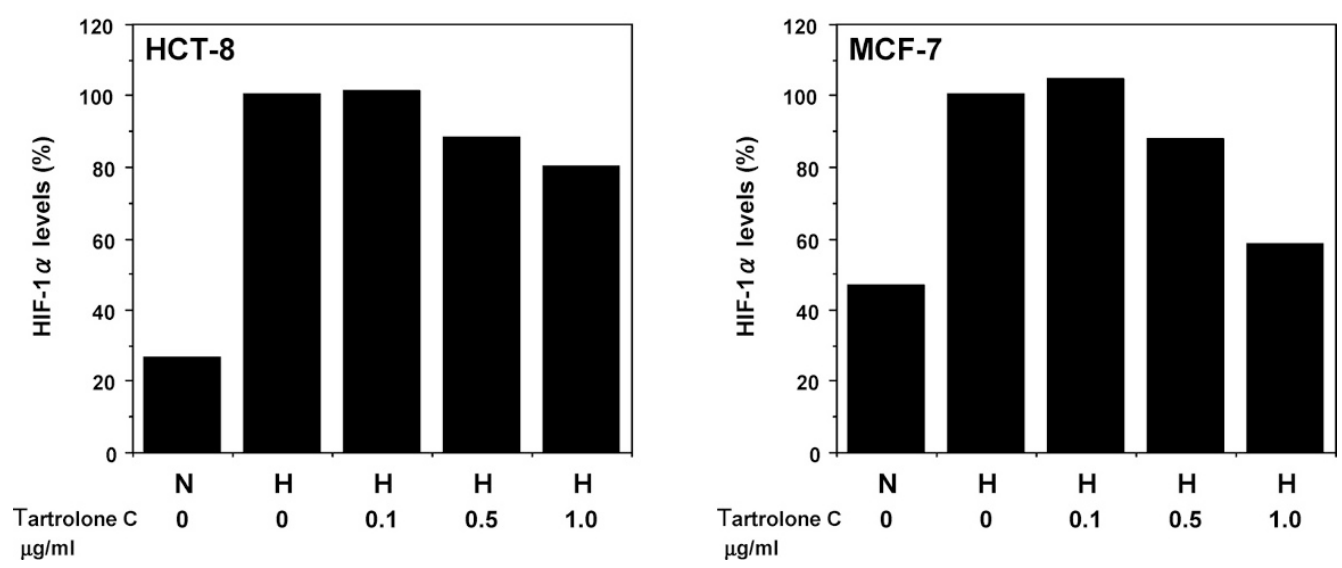

Fig. 4 Effect of tartrolone $\mathrm{C}$ on the expression of HIF-1 $\alpha$ protein.

A: The HIF-1 $\alpha$ protein levels were measured by Western blot. B: The quantification of the HIF-1 $\alpha$ protein levels by densitometry. Values were normalized to the $\beta$-actin levels. N: normoxic condition, $\mathrm{H}$ : hypoxic condition.

In summary, NBR1759-27 was isolated from the fermentaion broth of Streptomyces sp. by the screening system using a reporter under the control of the hypoxiaresponse element during hypoxia and then identified as tartrolone $\mathrm{C}$ through MS and NMR analysis. In the reporter gene assay, tartrolone $\mathrm{C}$ was found to inhibit the HIF-1 transcriptional activity under hypoxic conditions. Furthermore we have shown that tartrolone $\mathrm{C}$ decreased HIF- $1 \alpha$ protein levels under hypoxic conditions. HIF-1 is recognized as an attractive target for development of novel cancer therapeutics and there is a possibility that tartrolone $\mathrm{C}$ acts as an inhibitor of angiogenesis.

Acknowledgments The authors wish to thank Dr. R. Sawa and Ms. Y. Kubota for the spectral measurements, Dr. Y. Umezawa for the valuable support on ORTEP drawing. The authors also thank Dr. K. Yoza of Bruker AXS K. K. for X-ray analysis.

\section{References}

1. Shweiki D, Itin A, Soffer D, Keshet E. Vascular endothelial growth factor induced by hypoxia may mediate hypoxiainitiated angiogenesis. Nature 359: 843-845 (1992)

2. Brown JM, Wilson WR. Exploiting tumour hypoxia in cancer treatment. Nat Rev Cancer 3: 437-447 (2004)

3. Wang GL, Jiang BH, Rue EA, Semenza GL. Hypoxiainducible factor 1 is a basic-helix-loop-helix-PAS heterodimer regulated by cellular $\mathrm{O}_{2}$ tension. Proc Natl Acad Sci USA 92: 5510-5514 (1995)

4. Ivan M, Kondo K, Yang H, Kim W, Valiando J, Ohh M, Salic A, Asara JM, Lane WS, Kaelin WG Jr. HIF alpha targeted for VHL-mediated destruction by proline hydroxylation: implications for $\mathrm{O}_{2}$ sensing. Science 292: 464-468 (2001)

5. Jaakkola P, Mole DR, Tian YM, Wilson MI, Gielbert J, Gaskell SJ, Kriegsheim Av, Hebestreit HF, Mukherji M, Schofield CJ, Maxwell PH, Pugh CW, Ratcliffe PJ. Targeting of HIF-alpha to the von Hippel-Lindau ubiquitylation 
complex by $\mathrm{O}_{2}$-regulated prolyl hydroxylation. Science 292: 468-472 (2001)

6. Epstein AC, Gleadle JM, McNeill LA, Hewitson KS, O'Rourke J, Mole DR, Mukherji M, Metzen E, Wilson MI, Dhanda A, Tian YM, Masson N, Hamilton DL, Jaakkola P, Barstead R, Hodgkin J, Maxwell PH, Pugh CW, Schofield CJ, Ratcliffe PJ. C. elegans EGL-9 and mammalian homologs define a family of dioxygenases that regulate HIF by prolyl hydroxylation. Cell 107: 43-54 (2001)

7. Bruick RK, McKnight SL. A conserved family of prolyl-4hydroxylases that modify HIF. Science 294: 1337-1340 (2001)

8. Mabjeesh NJ, Post DE, Willard MT, Kaur B, Van Meir EG, Simons JW, Zhong H. Geldanamycin induces degradation of hypoxia-inducible factor 1alpha protein via the proteosome pathway in prostate cancer cells. Cancer Res 62: 2478-2482 (2002)

9. Rapisarda A, Uranchimeg B, Scudiero DA, Selby M, Sausville EA, Shoemaker RH, Melillo G. Identification of small molecule inhibitors of hypoxia-inducible factor 1 transcriptional activation pathway. Cancer Res 62:
4316-4324 (2002)

10. Mabjeesh NJ, Escuin D, LaVallee TM, Pribluda VS, Swartz GM, Johnson MS, Willard MT, Zhong H, Simons JW, Giannakakou P. 2ME2 inhibits tumor growth and angiogenesis by disrupting microtubules and dysregulating HIF. Cancer Cell 3: 363-375 (2003)

11. Powis G, Kirkpatrick L. Hypoxia inducible factor-1 alpha as a cancer drug target. Mol Cancer Ther 3: 647-654 (2004)

12. Kung AL, Zabludoff SD, France DS, Freedman SJ, Tanner EA, Vieira A, Cornell-Kennon S, Lee J, Wang B, Wang J, Memmert K, Naegeli HU, Petersen F, Eck MJ, Bair KW, Wood AW, Livingston DM. Small molecule blockade of transcriptional coactivation of the hypoxia-inducible factor pathway. Cancer Cell 6: 33-43 (2004)

13. Yamazaki Y, Egawa K, Nose K, Kunimoto S, Takeuchi T. HIF-1-dependent VEGF reporter gene assay by a stable transformant of CHO cells. Biol Pharm Bull 26: 417-420 (2003)

14. Lewer P, Chapin EL, Graupner PR, Gilbert JR, Peacock C. Tartrolone C: a novel insecticidal macrodiolide produced by Streptomyces sp. CP1130. J Nat Prod 66: 143-145 (2003) 